\title{
Evaluation of resistance pattern of the multi-drug resistant (MDR) bacteria isolated from burn wounds
}

\author{
Noshin Azra Rahman, Asma Akhter and Nusrat Jahan Urmi ${ }^{\star}$ \\ Department of Microbiology, Stamford University Bangladesh, 51 Siddeswari Road, Dhaka \\ 1217, Bangladesh
}

Received 21 March 2013/Accepted 7 May 2013

\begin{abstract}
Out of 10 random burn wound swab samples, 15 isolates were found which included Staphylococcus aureus, Klebsiella pneumoniae, Bacillus cereus, Shigella spp. Pseudmonas aeruginosa, Citrobacter spp. and Escherichia coli. Antibiogram assay revealed that four of them were multi-drug resistant (MDR) strains, i.e, Staphylococcus aureus, Klebsiella pneumoniae, Pseudomonas aeruginosa and E. coli which were further selected for a comparative analysis of resistance through determining minimum inhibitory concentration (MIC) and minimum bactericidal concentration (MBC) by using chloramphenicol and tetracycline. In case of tetracycline, the highest MIC value was estimated to be 30 $\mu \mathrm{g} / \mathrm{ml}$ and the highest MBC value was found to be $60 \mu \mathrm{g} / \mathrm{ml}$ for the 4 MDR strains tested. Whereas, against chloramphenicol, the highest MIC value was $62.5 \mu \mathrm{g} / \mathrm{ml}$ and the highest MBC value was 125 $\mu \mathrm{g} / \mathrm{ml}$ for all the MDR strains except for $E$. coli, which exhibited absolute resistance.
\end{abstract}

Key words: MDR; Chloramohenicol; Tetracycline; MIC; MBC

Burn wounds are extremely prone to infection as they present a suitable site for microbial proliferation. Infection is an important cause of mortality in burns. It has been estimated that $75 \%$ of all deaths following thermal injuries are related to infections (1). The rate of nosocomial infections are higher in burn patients due to various factors like nature of burn injury itself, immunocompromised status of the patients, invasive diagnostic and therapeutic procedures and prolonged ICU stay (2). Burn wounds can harbor more diverse groups of microbes than other wounds as they present already damaged cells with highly nutritious cell exudates. Clinical isolates are more prone to drug resistance than non-clinical isolates (3-5).

Chloramphenicol and tetracycline are considered as the prototypical broad-spectrum antibiotics. Chloramphenicol (45-60 mg chloramphenicol/kg body weight) (6) is effective against a wide variety of Grampositive and Gram-negative bacteria, including most anaerobic organisms. Due to resistance and safety concerns, it is no longer a first-line agent for any indication in developed nations, although it is sometimes used topically for eye infections $(7,8)$. It is not active against Pseudomonas aeruginosa but remains the first choice of treatment for staphylococcal infections. However, use of chloramphenicol has been reported to associate some side effects including aplastic anemia, bone marrow suppression, gray baby

${ }^{\ddagger}$ Correspondingauthor. Mailing address: Nusrat Jahan Urmi, Department of Microbiology, Stamford University Bangladesh, 51 Siddeswari Road, Dhaka1217, Bangladesh; E-mail: nusrat_mb@yahoo.com syndrome and leukaemia (9-12). Nevertheless, clinical burn wound isolates have been found to be resistant against the standard doses of chloramphenicol (13). Besides the problems projecting through the use of chloramphenicol, the general usefulness of tetracycline has also been rendered ineffective in many cases mostly due to the drug resistance. Resistance of Pseudomonas aeruginosa against tetracycline has been significantly noted in burn patients $(13,14)$.

Based on these evidences, the present study was conducted to understand the efficacy of the two most common broad-spectrum antibiotics, chloramphenicol and tetracycline, against the emerging MDR clinical bacteria.

\section{MATERIALS AND METHODS}

10 samples were randomly collected from burn patients admitted in Dhaka Medical College Hospital (DMCH) Burn Unit using sterile cotton swabs. After a series of laboratory techniques including the examination of growth on Mannitol salt agar, Eosin-methylene blue, MacConkey agar, Xylose lysine deoxycholate agar and Cetrimide agar, 15 isolates were identified (including Bacillus cereus, Shigella spp., Citrobacter spp., Staphylococcus aureus, Klebsiella pneumoniae, Pseudomonas aeruginosa and E. coli) and confirmed through morphological and biochemical tests. Applying the Kirby Bauer antibiotic disc diffusion method (15) against Penicillin (PG10), Gentamycin (GM10), Ampicillin (AP10), Chloramohenicol (C30), Nalidixic acid (NA30), Novobiocin (NO30), Imipenem (IPM10), Ciprofloxacin (CIP5), Tetracycline (T30), Vancomycin (VA30), Mezlociline (MZ75) and Trimethoprim-sulphamethoxozole (SXT25), the most resistant strains (Staphylococcus aureus, Klebsiella pneumoniae, Pseudomonas aeruginosa and $E$. coli) were selected for further study.

To prepare the stock solution of chloramphenicol, $10 \mathrm{mg}$ of chloramphenicol powder was weighed and re-suspended in $10 \mathrm{ml}$ of sterile distilled water resulting in the final concentration of $1 \mathrm{mg} / \mathrm{ml}$ chloramphenicol solution. For the working solution, $250 \mu \mathrm{l}$ of the stock solution was added to $750 \mu \mathrm{l}$ of sterile distilled water. This gave a working solution of $250 \mu \mathrm{g} / \mathrm{ml}$ chloramphenicol solution. A 4 times two-fold dilution was used for conducting the MIC and MBC $(125 \mu \mathrm{g} / \mathrm{ml}, 62.5$ $\mu \mathrm{g} / \mathrm{ml}, 31.25 \mu \mathrm{g} / \mathrm{ml}$ and $15.625 \mu \mathrm{g} / \mathrm{ml}$ ). An initial load of approximately $10^{8}$ cells (0.5 McFarland standard) were introduced in to each tube. 
For the tetracycline stock solution, $10 \mathrm{mg}$ of sterile tetracycline powder was added to $10 \mathrm{ml}$ of sterile distilled water to give a final concentration of $1 \mathrm{mg} / \mathrm{ml}$. From this stock solution $60 \mu \mathrm{l}$ was pipetted out to be added to $940 \mu \mathrm{l}$ of sterile distilled water giving a final concentration of $60 \mu \mathrm{g} / \mathrm{ml}$. For the MIC and MBC experiments, a 4 times two-fold dilution was used $(30 \mu \mathrm{g} / \mathrm{ml}, 15 \mu \mathrm{g} / \mathrm{ml}, 7.5$ $\mu \mathrm{g} / \mathrm{ml}$ and $3.75 \mu \mathrm{g} / \mathrm{ml})$. A load of approximately $10^{8}$ cells $(0.5 \mathrm{McF}$ arland standard) was used in each tube.

\section{RESULTS}

After conducting the antibiotic sensitivity tests against PG10, GM10, AP10, C30, SXT25, NA30, NO30, CIP5, IPM10, T30, MZ75 and VA30, Klebsiella pneumoniae, Pseudomonas aeruginosa and E. coli were found to be resistant against all the antibiotic discs except Imipenem $(10 \mu \mathrm{g})$ and Staphylococcus aureus showed resistance against all antibiotics except Chloramphenicol (30 $\mu \mathrm{g})$, Tetracycline $(30 \mu \mathrm{g})$ and Imipenem $(10 \mu \mathrm{g})$. Bacillus cereus, Shigella spp., Citrobacter spp. were found to be more susceptible than Staphylococcus aureus, Klebsiellapneumoniae, Pseudomonas aeruginosa and E. coli (Table 1).

$S$. aureus, $K$. pneumoniae, $P$. aeruginosa and E. coli were subjected to high concentrations of chloramphenicol and tetracycline, two common broad spectrum antibiotics. The MIC for $S$. aureus, $K$. pneumoniae, and $P$. aeruginosa were $15.625 \mu \mathrm{g} / \mathrm{ml}$, $62.5 \mu \mathrm{g} / \mathrm{ml}$ and $31.25 \mu \mathrm{g} / \mathrm{ml}$ respectively for chloramphenicol; and $15 \mu \mathrm{g} / \mathrm{ml}, 30 \mu \mathrm{g} / \mathrm{ml}$ and $30 \mu \mathrm{g} / \mathrm{ml}$, respectively for tetracycline. The $\mathrm{MBC}$ for $S$. aureus, $K$. pneumoniae, and $P$. aeruginosa were $31.25 \mu \mathrm{g} / \mathrm{ml}, 125$ $\mu \mathrm{g} / \mathrm{ml}$ and $62.5 \mu \mathrm{g} / \mathrm{ml}$ for chloramphenicol (Table 2) and $30 \mu \mathrm{g} / \mathrm{ml}, 60 \mu \mathrm{g} / \mathrm{ml}$ and $60 \mu \mathrm{g} / \mathrm{ml}$ for tetracycline (Table 3), respectively. Even though, E. coli was sensitive to high doses of tetracycline (MBC measuring $60 \mu \mathrm{g} / \mathrm{ml}$ ), it showed absolute resistance to chloramphenicol.

\section{DISCUSSION}

Current studies have left little doubt that popular antibiotics are becoming more and more unsuccessful due to the emergence of MDR bacterial strains. Interestingly the clinical samples have been proven to be more resistant than other samples.

Intrigued by these facts, the current study was planned. The purpose was to carry out MIC and MBC for some commonly used popular antibiotics and evaluate their efficacy against clinical samples. Chloramphenicol is such a drug that has faced a fall in its popularity as a therapeutic agent. In consistence to the other studies, the present study also reveals that the clinical samples are more resistant to chloramphenicol (Klebsiella pneumoniae having an $\mathrm{MBC}$ of $125 \mu \mathrm{g} / \mathrm{m} 1$ and E. coli showing absolute resistance). This may be as chloramphenicol causes a bacteriostatic effect by binding to the 50S ribosomal subunit and inhibiting the transpeptidation step in protein synthesis. Resistance may occur by any of three mechanisms, by reducing membrane permeability, 50S ribosomal subunit modification or enzymatically elaborating chloramphenicol acetyltransferase (16-19).

TABLE 1. Antibiogram of pathogenic bacterial isolates from burn wounds

\begin{tabular}{|c|c|c|c|c|c|c|c|c|c|c|c|c|}
\hline \multirow{3}{*}{ Organisms } & \multicolumn{12}{|c|}{ Antibiotic } \\
\hline & PG & GM & $\mathrm{AP}$ & $\mathrm{C}$ & SXT & NA & $\mathrm{NO}$ & CIP & IPM & $\mathrm{T}$ & MZ & VA \\
\hline & 10 & 10 & 10 & 30 & 25 & 30 & 30 & 5 & 10 & 30 & 75 & 30 \\
\hline S. aureus & $\mathrm{R}$ & $\mathrm{R}$ & $\mathrm{R}$ & $\mathrm{S}$ & $\mathrm{R}$ & $\mathrm{R}$ & $\mathrm{R}$ & $\mathrm{R}$ & $\mathrm{S}$ & $\mathrm{S}$ & $\mathrm{R}$ & $\mathrm{R}$ \\
\hline Bacillus cereus & $S$ & $\mathrm{R}$ & $\mathrm{R}$ & S & $\mathrm{R}$ & $\mathrm{R}$ & $\mathrm{R}$ & $\mathrm{R}$ & $\mathrm{S}$ & $\mathrm{S}$ & $\mathrm{R}$ & $\mathrm{R}$ \\
\hline Shigella spp. & $\mathrm{R}$ & $\mathrm{S}$ & $\mathrm{S}$ & $\mathrm{S}$ & $\mathrm{R}$ & $\mathrm{R}$ & $\mathrm{R}$ & $\mathrm{R}$ & $S$ & $\mathrm{~S}$ & $\mathrm{R}$ & $\mathrm{R}$ \\
\hline E. coli & $\mathrm{R}$ & $\mathrm{R}$ & $\mathrm{R}$ & $\mathrm{R}$ & $\mathrm{R}$ & $\mathrm{R}$ & $\mathrm{R}$ & $\mathrm{R}$ & S & $\mathrm{R}$ & $\mathrm{R}$ & $\mathrm{R}$ \\
\hline P. aeruginosa & $\mathrm{R}$ & $\mathrm{R}$ & $\mathrm{R}$ & $\mathrm{R}$ & $\mathrm{R}$ & $\mathrm{R}$ & $\mathrm{R}$ & $\mathrm{R}$ & S & $\mathrm{R}$ & $\mathrm{R}$ & $\mathrm{R}$ \\
\hline Citrobacter spp. & $\mathrm{R}$ & $\mathrm{R}$ & $\mathrm{R}$ & S & S & $\mathrm{R}$ & $\mathrm{R}$ & S & S & $\mathrm{S}$ & $\mathrm{R}$ & $\mathrm{R}$ \\
\hline K. pneumoniae & $\mathrm{R}$ & $\mathrm{R}$ & $\mathrm{R}$ & $\mathrm{R}$ & $\mathrm{R}$ & $\mathrm{R}$ & $\mathrm{R}$ & $\mathrm{R}$ & $S$ & $\mathrm{R}$ & $\mathrm{R}$ & $\mathrm{R}$ \\
\hline
\end{tabular}

PG10 = Penicillin G $10 \mu \mathrm{g}$; GM10 = Gentamicin $10 \mu \mathrm{g}$; AP10 = Ampicilin $10 \mu \mathrm{g}$; C30 = Chloramphenicol $30 \mu \mathrm{g}$; SXT25 = Trimethoprimsulphamethoxozole $25 \mu \mathrm{g}$; NA30 = Nalidixic acid $30 \mu \mathrm{g}$; NO30 = Novobiocin $30 \mu \mathrm{g}$; CIP5 = Ciprofloxacin $5 \mu \mathrm{g}$; IPM10 = Imipenem $10 \mu \mathrm{g}$; T30 = Tetracycline $30 \mu \mathrm{g} ;$ MZ75 = Mezlocilin $\mu \mathrm{g} ; \mathrm{VA30}=$ Vancomycin $30 \mu \mathrm{g}$

TABLE 2. MBC values against chloramphenicol

\begin{tabular}{|c|c|c|c|c|c|c|}
\hline \multirow{2}{*}{ Organisms } & \multicolumn{5}{|c|}{ Concentration of Chloramphenicol $(\mu \mathrm{g} / \mathrm{ml})$} & \multirow{2}{*}{ MBC value } \\
\hline & 250 & 125 & 62.5 & 31.25 & 15.125 & \\
\hline S. aureus & - & - & - & - & + & $31.25 \mu \mathrm{g} / \mathrm{ml}$ \\
\hline E. coli & + & + & + & + & + & Absolute resistance \\
\hline P. aeruginosa & - & - & - & + & + & $62.5 \mu \mathrm{g} / \mathrm{ml}$ \\
\hline K. pneumoniae & - & - & + & + & + & $125 \mu \mathrm{g} / \mathrm{ml}$ \\
\hline
\end{tabular}


TABLE 3. MBC values against tetracycline

\begin{tabular}{cccccccc}
\hline \multirow{2}{*}{ Organisms } & \multicolumn{5}{c}{ Concentration of Tetracycline $(\mu \mathrm{g} / \mathrm{ml})$} & \multicolumn{1}{c}{ MBC } \\
\cline { 2 - 6 } value \\
\hline S. aureus & 60 & 30 & 15 & 7.5 & 3.75 & \\
E. coli & - & - & + & + & + & $30 \mu \mathrm{g} / \mathrm{ml}$ \\
P. aeruginosa & - & + & + & + & + & $60 \mu \mathrm{g} / \mathrm{ml}$ \\
K.pneumoniae & - & - & + & + & + & $30 \mu \mathrm{g} / \mathrm{ml}$ \\
\hline
\end{tabular}

Resistance to chloramphenicol in $S$. aureus is most frequently due to the activity of an inducible detoxification enzyme, chloramphenicol acetyltransferase (20).

Tetracycline, though not as unsuccessful as chloramphenicol, has been ineffective in many clinical cases. In this study, E. coli and Klebsiella pneumoniae had an MBC of $60 \mu \mathrm{g} / \mathrm{ml}$ whereas tetracycline reaches a concentration of $5-12 \mu \mathrm{g} / \mathrm{ml}$ after a single dose of 250 $\mathrm{mg}$ or $500 \mathrm{mg}$ dose (21).

Our recent study encourages herbal or natural remedies rather than traditional antibiotic drugs. Aloe barbadensis, used as a natural remedy for burn since ancient times, was proven as an answer to MDR bacteria (13). Aloe barbadensis was successful in preventing MDR bacterial growth in more effectively in comparison to traditional antibiotics (13). In recent years, a range of wound dressings with slow-release silver (Ag) compounds have been introduced, including Acticoat, Actisorb Silver, Silverlon, and others. They propose a better answer to MDR bacterial threats (22). In light of this current study, it is evident that traditional antibiotics used for therapeutic reasons are becoming more and more ineffective due to the rise of MDR bacteria or the so called "superbugs". Studies should be conducted to find reliable and successful alternative medications for these MDR bacterial strains.

\section{ACKNOWLEDGEMENTS}

Authors thank Stamford University Bangladesh for the technical facilities and financial support to carry out the experiments.

\section{REFERENCES}

1. Vindenes, H., and R. Bjerknes. 1995. Microbial colonization of large wounds. Burns 21 (8): 575-579.

2. Pruitt, B. A., A. T. MacManus, S. H. Kim, and C. W. Goodwin. 1997. Burn Wound infections: current status. World J. Surg. 22: 135-145.

3. Greenland, S. 2001. Ecologic versus individual-level sources of bias in ecologica estimates of contextual health effects. Int. J. Epidemiol, 30: $1343-1350$
4. Koopman, J. S., and I. M. Longini. 1994. The ecological effects of individual exposures and nonlinear disease dynamics in populations. Am. J. Public Health 84: 836-842.

5. Steinke, D., and P. Davey. 2001. Association between antibiotic resistance and community prescribing: a critical review of bias and confounding in published studies. Clin. Infec. Dis. 33 (Sppl 3): S193-S209.

6. Arrioja-Dechert, A. 2006. Compendium of veterinary products. North American Compendiums, Inc., Port Huron, MI.

7. Falagas, M. E., A. P. Grammatikos, A. Michalopoulos. 2008. Potential of old-generation antibiotics to address current need for new antibiotics. Expert Review of Anti Infective Therapy 6 (5): 593-600.

8. Rose, C., et al. 2002. Emergence of resistance of vancomycin-resistant Enterococcus faecium in a thermal injury patient treated with quinupristindalfopristin and cultured epithelial autografts for wound closure. Burns 28 (7): 696-8.

9. Rich, M., R. Ritterhoff, and R. Hoffmann. 1950. A fatal case of aplastic anemia following chloramphenicol (chloromycetin) therapy. Annals of Internal Medicine 33 (6): 1459-1467.

10. Yunis, A. A. 1989. Chloramphenicol toxicity: 25 years of research. Am. J. Med. 87 (3N): $44 \mathrm{~N}-48 \mathrm{~N}$

11. McIntyre, J., and I. Choonara. 2004. Drug toxicity in the neonate. Biology of the Neonate 86 (4): 218-221.

12. Shu, X., et al. 1987. Chloramphenicol use and childhood leukaemia in Shanghai. Lancet 2 (8565): 934-937.

13. Rahman, N. A., and S. R. Rahman. 2010. Multidrug-resistant (MDR) bacteria associated with burn wound infections and antimicrobial activity of leaf gel of Aloe barbadensis against some isolates. Bangladesh Journal of Medical Science 16 (1): 33-37.

14. Ranjbar, R., et al. 2011. Characterization of Pseudomonas aeruginosa strains isolated from burned patients hospitalized in a major burn center in Tehran, Iran. Acta MedicaIranica 49 (10): 675-679.

15. Bauer, A. W., W. M. Kirby, J. C. Sheris, and M. Turck. 1966. Antibiotic susceptibility testing by a standardized single disc method. Am. J. Clin. Pathol. 45: 149-158

16. Butaye, P., A. Cloeckaert, and S. Schwarz. 2003. Mobile genes coding for efflux-mediated antimicrobial resistance in Gram- positive and Gramnegative bacteria. Int. J. Antimicrob. Agents 22: 205-210.

17. Paulsen, I. T., M. H. Brown, and R. A. Skurry. 1996. Proton- dependent multidrug efflux systems. Microbiol. Rev. 60: 575-608.

18. Toro, C. S., et al. 1990. Clinical isolates of a porin-less Salmonella typhi resistant to high levels of chloramphenicol. Antimicrob. Agents Chemother. 34: $1715-1719$.

19. Ettayebi, M., S. M. Prasad, and E. A. Morgan. 1985. ChloramphenicolErythromycin resistance mutations in a 23S rRNA gene of Escherichia coli. J. Bacteriol. 162: 551-557.

20. Murray, I., A. and W. V. Shaw. 1997. O-acetyltransferases for chloramphenicol and other natural products. Antimicrob. Agents Chemother 41 (1): 1-6.

21. Gordon, J. M., et al. 1981. Concentration of tetracycline in human gingival fluid after single doses. J. Clin. Periodontol. 8 (2):117-121.

22. Silver, S., L. T. Phung, and G. Silver. 2006. Silver as biocides in burn and wound dressings and bacterial resistance to silver compounds. Journal of Industrial Microbiology and Biotechnology 33 (7): 627-634. 